\title{
The Importance of Work Stress and K3 (Occupational Health and Safety) in Assessing Employee Performance
}

\author{
Indah Nihayati, Moh. Saiful Bahri, Agustina Pujiastuti, Agung Yatiningrum \\ Department of Management, Universitas Panca Marga Probolinggo, Probolinggo, East Java, Indonesia \\ Email: saiful.bahri@upm.ac.id
}

\section{A R T I C L E I N F O}

Received:

14 January 2021

Revised:

7 March 2021

Accepted:

15 March 2021

\begin{abstract}
A B S T R A C T
It is very important to pay attention to factors that can affect employee performance, such as work stress experienced by employees or occupational safety and health. This research was conducted at PT. Akas Mila Sejahtera Probolinggo with the objectives (1) To determine the simultaneous effect of work stress and K3 (Occupational Health and Safety) on employee performance. (2) To determine the partial effect of work stress and K3 (Occupational Health and Safety) on employee performance. (3) To determine the dominant influence between work stress and K3 (Occupational Health and Safety) on employee performance. The population of this research is the employees of PT. Akas Mila Sejahtera City of Probolinggo, amounting to 90 people. The sample taken by the Slovin method is as many as 73 people, with the criteria of employees who work as drivers, kondiktur, kernet and workshops with incidental data collection techniques. The approach used is quantitative with analysis using SPSS software. The results showed that work stress and K3 (Occupational Health and Safety) had a significant effect on employee performance.
\end{abstract}

Keywords: Job Stres, Occupational Health and Safety, Employee Performance

Cite this as: Nihayati, I., Bahri, M. S., Pujiastuti, A., Yatiningrum, A. (2021). The Importance of Work Stress and K3 (Occupational Health and Safety) in Assessing Employee Performance. Wiga : Jurnal Penelitian Ilmu Ekonomi, 11(1), 57-62. https://doi.org/10.30741/wiga.v11i1.607

\section{INTRODUCTION}

To improve employee performance, it is very important to pay attention to factors that can affect employee performance, such as work stress experienced by employees or occupational safety and health (K3). According to Afandi (2018: 174) "Job stress is defined as an internal or external response or process that reaches a level of physical and psychological tension to the limit or exceeds the ability of employees". 
In addition to work stress, factors that can affect performance are K3 (Occupational Health and Safety). According to Sedarmayanti (2018: 373) "The definition of occupational safety and health (K3) is technically defined as a protection effort aimed at ensuring that employees / labor and other people in the workplace are safe and healthy, so that every production source can be used continuously. safe and efficient".

Through improvements to the K3 system carried out by the company on an ongoing basis, it can support a company that has an effect on improving performance. According to Mangkunegara (2017: 09) "Employee performance (work performance) is the result of work in quality and quantity achieved by a workforce in carrying out tasks in accordance with the responsibilities assigned to him".

PT. Akas Mila Sejahtera Probolinggo is one of the companies that runs its business in the field of public transportation, especially buses. In its business activities, PT. Akas Mila Sejahtera Probolinggo provides urban and intercity transportation services. In order to maintain the quality of its services, the company always improves its performance through prevention of work stress and the existence of a K3 (Occupational Health and Safety) program. Work stress prevention is carried out by providing a workload that is in accordance with the employee's capacity, supervision carried out on employees during work and handling of work conflicts or when an accident occurs. Meanwhile, for occupational safety and health, company employees apply certain rules such as dress neatly / uniformly and wearing shoes, not consuming illegal drugs, prohibiting violating traffic signs, not using cellphones while driving and helping to keep the bus clean. With the background that has been described, the formulation of the problem of this research is 1). How is the simultaneous influence between work stress and K3 (Occupational Health and Safety) on employee performance? 2). How is the partial influence of work stress and K3 (Occupational Health and Safety) on employee performance? 3). Which one has the dominant influence between work stress and K3 (Occupational Health and Safety) on employee performance?

\section{METHOD}

This type of research is quantitative research by looking for a cause and effect relationship. The data source used comes from primary and secondary data. Primary data in this study include employees at PT. Akas Mila Sejahtera Probolinggo, through distributing questionnaires about work stress and K3 (Occupational Health and Safety) and Employee Performance. Secondary data can be obtained from companies such as an overview of PT. Akas Mila Sejahtera Probolinggo, organizational structure, number of workers and other data related to this research. As many as 73 employees of PT. Akas Mila Sejahtera Probolinggo was used as a sample. Data analysis used descriptive statistics in the form of multiple linear regression analysis and determination because this is related to the calculation to answer the problem formulation and hypothesis testing using statistics and processing using Statistical Packages for Science (SPSS) v.22.0. The data analysis method used to test, among others, test the validity and reliability, classical assumption test, multiple linear regression, coefficient of determination (R2) and hypothesis testing and dominant test.

\section{RESULTS AND DISCUSSION}

The validity test is used to measure the validity of a questionnaire. This validity test is carried out by comparing rcount with rtable. If $r_{\text {test }}>r_{\text {table }}$ is declared valid, if $r_{\text {test }}<r_{\text {table }}$ is declared invalid. Where $\mathrm{df}=73-2=71$ with alpha significance of $5 \%$. 
Table 1. Validity Test

\begin{tabular}{lcccc}
\hline \multicolumn{1}{c}{ Variable } & No & $\mathbf{r}_{\text {table }}$ & $\mathbf{r}_{\text {test }}$ & \\
\hline & 1 & 0,2303 & 0,718 & Valid \\
& 2 & 0,2303 & 0,544 & Valid \\
& 3 & 0,2303 & 0,568 & Valid \\
Job Stress & 4 & 0,2303 & 0,554 & Valid \\
(X1) & 5 & 0,2303 & 0,590 & Valid \\
& 6 & 0,2303 & 0,515 & Valid \\
& 7 & 0,2303 & 0,455 & Valid \\
& 8 & 0,2303 & 0,421 & Valid \\
& 9 & 0,2303 & 0,499 & Valid \\
& 10 & 0,2303 & 0,412 & Valid \\
\hline \multirow{3}{*}{ K3 (X2) } & 1 & 0,2303 & 0,711 & Valid \\
& 2 & 0,2303 & 0,568 & Valid \\
& 3 & 0,2303 & 0,715 & Valid \\
& 4 & 0,2303 & 0,694 & Valid \\
& 5 & 0,2303 & 0,612 & Valid \\
& 6 & 0,2303 & 0,529 & Valid \\
Employee Performance & 1 & 0,2303 & 0,644 & Valid \\
(Y1) & 2 & 0,2303 & 0,638 & Valid \\
& 3 & 0,2303 & 0,525 & Valid \\
& 4 & 0,2303 & 0,612 & Valid \\
& 5 & 0,2303 & 0,732 & Valid \\
& 6 & 0,2303 & 0,750 & Valid \\
& 7 & 0,2303 & 0,668 & Valid \\
\hline
\end{tabular}

Source: Primary data processed in 2020

Observing table 1 that the variables of Work Stress and K3 (Occupational Health and Safety) have $\mathrm{r}_{\text {test }}>\mathrm{r}_{\text {table }}$, so it can be said that all the concepts of measuring Work Stress and K3 (Occupational Health and Safety) variables used in this study are valid. The validity test for each statement of the employee performance variable shows the value of $r_{\text {test }}>r_{\text {table }}=0.2303$, so the employee performance variable is valid and can be analyzed further.

Table 2. Reliability Test

\begin{tabular}{llll}
\hline \multicolumn{1}{c}{ Variable } & Cronbach's Alpha & Criticle Value & \\
\hline Job Stress (X1) & 0,700 & 0,60 & Reliabel \\
\hline K3 (X2) & 0,704 & 0,60 & Reliabel \\
\hline Employee Performance (Y) & 0,774 & 0,60 & Reliabel \\
\hline
\end{tabular}

Source: Primary data processed in 2020

Based on table 2, it can be seen that the Cronbachs Alpha value of all variables is greater than 0.60. From the results of this reliability test it can be concluded that all lists of statements (instruments) are reliable.

The Classical Assumption Test in this study used the data normality test, multicollinearity, and heteroscedasticity.

Normality Test 

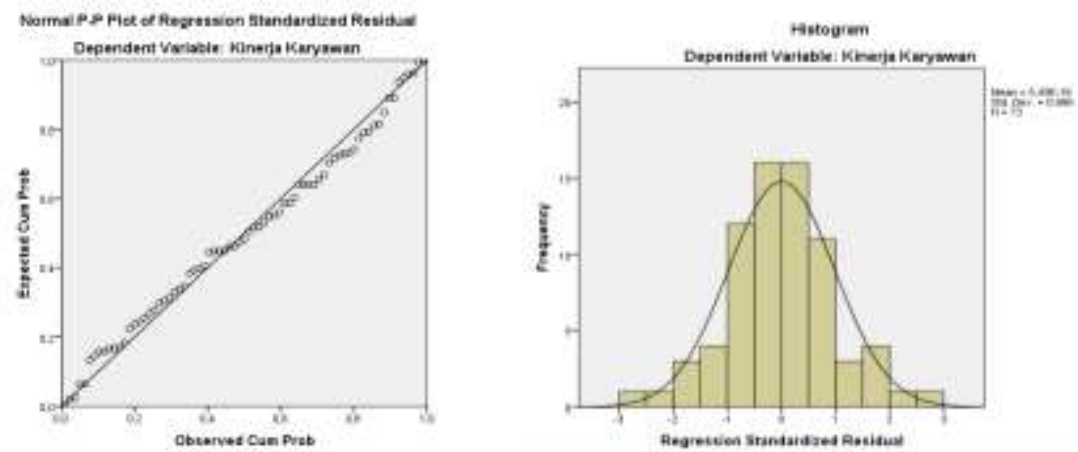

Figure 1. Normality Test Results

Source: Primary data processed in $\mathbf{2 0 2 0}$

Pengujian normalitas dilakukan terhadap residual regresi dengan menggunakan grafik P-Plot. Data normal adalah data yang membentuk titik menyebar tidak jauh dari garis diagonal. Hasil uji data menunjukkan bahwa titik-titik data berada tidak jauh dari garis diagonal. Kondisi ini menunjukkan bahwa model regresi tersebut sudah berdistribusi normal.

Table 3. Multicolonierity Test Result

\begin{tabular}{lcc}
\hline \multirow{2}{*}{ Constanta } & \multicolumn{2}{c}{ Collinearity Statistics } \\
\cline { 2 - 3 } & & Standard Eror \\
\hline Job Stress (X1) & 1,006 & 3,166 \\
\hline K3 (X2) & 1,006 &, 057 \\
\hline
\end{tabular}

Source: Primary data processed in 2020

The multicolonierity test results in table 3 prove that the VIF value of the work stress variable is 1.006 and the K3 (Occupational Health and Safety) variable is 1.006. The test results show that the VIF value is smaller than 10 . This means that the regression model does not have a correlation between the independent variables or there is no multicollinearity.

The heteroscedasticity test is needed to test for differences in residual variance from the observation period to another observation period. The results of the heteroscedasticity test are as follows

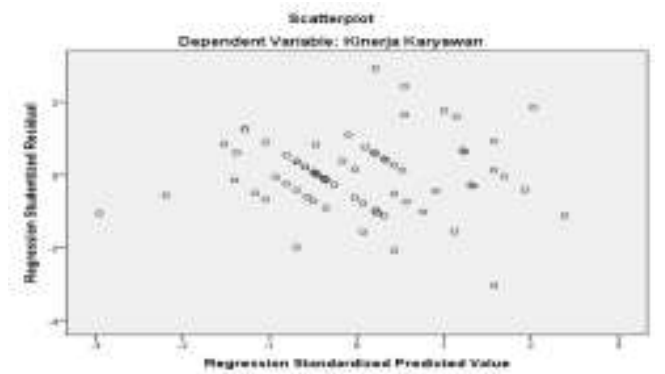

Figure 2. Heteroscedasticity Test Result Source: Primary data processed in 2020

The results of the heteroscedasticity test showed that there was no clear pattern from these points. This shows that the regression model does not have heteroscedasticity symptoms, meaning that the regression model has no interference, so this model is suitable to be used to predict performance based on the variables that influence it, namely work stress and K3 (Occupational Health and Safety). 
Table 4. Multiple Linear Regression Analysis

\begin{tabular}{|c|c|c|c|c|c|}
\hline \multirow{2}{*}{ Model } & \multicolumn{2}{|c|}{ UnStandar Coefisien } & \multirow{2}{*}{$\frac{\text { Standar Coefisien }}{\text { B }}$} & \multirow[b]{2}{*}{$\mathbf{t}$} & \multirow[b]{2}{*}{ sig } \\
\hline & B & S Error & & & \\
\hline Constant & 15,927 & 3,166 & & 5,031 & 0,00 \\
\hline Job Stress &,- 226 &, 057 &,- 267 & $-3,989$ & 0,00 \\
\hline K3 &, 860 & ,075 &, 766 & 11,459 & 0,00 \\
\hline
\end{tabular}

Source: Primary data processed in 2020

Based on the data in table 5, the multiple regression equation is compiled, namely $\mathrm{Y}=15.927+(-$ $0.226) \mathrm{X} 1+0.860 \mathrm{X} 2$ this form of regression equation has the following meanings: a. Constanta a $=15,927$. This constant value gives the sense that without work stress and K3 / Occupational Safety and Health (when $\mathrm{X}=0$ ), then the performance is worth 15.927 . b. Job stress regression coefficient. The coefficient value of work stress for variable X1 is -0.226 and is negative, meaning that if the work stress variable has increased by $1 \%$ due to high company targets, conflicts with superiors or fellow colleagues and an uncomfortable work environment, and Occupational Health) are assumed to be constant, it will cause a decrease in employee performance by 0.226 . The coefficient value shows that the value of job stress has a negative effect on employee performance. This illustrates when job stress has increased, then employee performance will decrease. c. K3 regression coefficient (Occupational Health and Safety). The coefficient value for variable X2 is 0.860 and is positive, meaning that if the K3 (Occupational Health and Safety) variable has increased by $1 \%$ due to adequate work protective equipment, adequate health insurance and adequate standard work procedures while work stress is assumed to remain constant., it will cause an increase in employee performance of 0.860 . The coefficient value shows that the value of K3 (Occupational Health and Safety) has a positive effect on employee performance. This illustrates when K3 (Occupational Health and Safety) has increased, the employee's performance will also increase.

Table 6. Coefficient of Determination

\begin{tabular}{cccc}
\hline $\mathbf{R}$ & R Square & Ajusted RSquare & Standar Error estimate \\
\hline 0,830 & 0,689 & 0,680 & 1,295 \\
\hline
\end{tabular}

Sumber: Data diolah 2020

Dari tabel 6 menunjukkan nilai R sebesar 0,830. Nilai $R$ Square sebesar 0,689 atau $68,9 \%$. Hal ini menunjukkan bahwa variasi kinerja karyawan 68,9 \% dipengaruhi oleh stres kerja dan K3 (Keselamatan dan Kesehatan Kerja) sedangkan 31,1\% dipengaruhi oleh variabel lain yang tidak diteliti dalam penelitian ini.

Tabel 7. Hasil ji F

\begin{tabular}{llllll}
\hline Model & Sum of Square & Df & Mean Square & F & Sig \\
\hline Regresion & 259,894 & 2 & 129,947 & 77,450 & 0,00 \\
\hline Residual & 117,448 & 70 & 1,678 & & 0,00 \\
\hline Total & 377,342 & 72 & & & 0,00
\end{tabular}

Source: Primary data processed in 2020

Based on table 7 above, it is known that the sig value is 0.000 and $F_{\text {test }}$ is 77.450 and $F_{\text {table }}$ is 3.13. Because $F_{\text {test }}>F_{\text {table }}$ then Ho is rejected, in other words there is a significant influence between work stress and K3 (Occupational Health and Safety) simultaneously on employee performance. Thus the first hypothesis is proven or accepted that "there is a simultaneous significant influence between work stress and K3 (Occupational Health and Safety) on employee performance at PT. Akas Mila Sejahtera Probolinggo".

Paying attention to table 5 can be explained as follows: 1. Variable X1 (Job Stress) obtained tcount $=-3,989$ greater than table $=1.994$ with a sig $t=0.000$ value, because the sig value $<0.05$, this 
means that there is a significant influence between job stress on employee performance. 2 . The variable X2 (K3 / Occupational Safety and Health) obtained the value of $\mathrm{t}$ count $=11.459$ which is greater than $\mathrm{t}$ table $=1.994$ with a value of $\operatorname{sig} \mathrm{t}=0.000$, because the value of $\operatorname{sig}<0.05$, this has a significant influence between K3 (Safety and Health). Work) on employee performance.

Thus the second hypothesis which reads "there is a partially significant influence between work stress and K3 (Work Safety and Health) on employee performance" is accepted or proven.

Based on the partial test above, where the $t$ value for the work stress variable is $-3,989$ and the tcount value for the K3 variable (Occupational Safety and Health) is 11.459, this shows that the tcount value of the K3 variable (Occupational Safety and Health) is greater than the work stress variable. This means that the K3 (Occupational Health and Safety) variable has a dominant effect on employee performance, thus the third hypothesis can be accepted.

\section{CONCLUSION}

Based on the results of the research hypothesis test, it can be concluded as follows: a. Simultaneously, work stress and K3 (Occupational Health and Safety) have a significant effect on employee performance. b. Partially, work stress and K3 (Occupational Health and Safety) have a significant effect on employee performance. c. K3 (Occupational Health and Safety) has a dominant effect on employee performance.

\section{REFERENCE}

Afandi, P. (2018). Manajemen Sumber Daya Manusia Teori, Konsep dan Indikator. Pekanbaru Riau: Zanafa Publishing.

Arikunto, S. (2013). Prosedur Penelitian Suatu Pendekatan Praktik. Jakarta: PT. Rineka Cipta.

Bhastary, M. D., \& Suwardi, K. (2018). Analisis Pengaruh Keselamatan dan Kesehatan kerja (K3) dan Lingkungan kerja terhadap Kinerja Karyawan di PT. Samudera Perdana. Jurnal Manajemen dan Keuangan, 7(1).

Budiarto. (2017). Key Performance Indicator (KPI). Depok: Huta Publisher.

Hamali, A. Y. (2016). Pemahaman Manajemen Sumber Daya Manusia Strategi Mengelola Karyawan. Yogyakarta: PT. Buku Seru.

Mangkunegara, A. P. (2015). Manajemen Sumber Daya Manusia Perusahaan. Bandung: PT. Remaja Rosdakarya.

Mangkunegara, A. P. (2017). Evaluasi Kinerja SDM. Bandung: PT. Revika Aditama.

Marwansyah. (2012). Manajemen Sumber Daya Manusia. Bandung: Alfabeta.

Nugroho, Y. A. (2011). Olah Data dengan SPSS. Yogyakarta: PT. Skripta Media Creative.

Oemar, U., \& Gangga, L. (2017). Pengaruh Stres Kerja terhadap Kinerja Pegawai pada Dinas Pendapatan, Keuangan dan Aset Daerah Kabupaten Musi Manyuasin. Jurnal Ecoment Global, 2(2): 22-34.

Riniwati, H. (2016). Manajemen Sumber Daya Manusia. Malang: UB Press.

Sedarmayanti. 2018. Perencanaan dan Pengembangan SDM untuk Meningkatkan Kompetensi, Kinerja dan Produktivitas Kerja. Bandung : PT. Refika Aditama

Sugiyono. (2016). Metode Penelitian Kuantitatif, Kualitatif dan R\&D. Bandung: Alfabeta.

Sujarweni, W. (2015). Metodologi Penelitian Bisnis \& Ekonomi. Yogyakarta: PT. Pustaka Baru.

Sunaryanto, K. (2015). Pengaruh keselamatan dan Kesehatan Kerja (K3) serta Stres Kerja terhadap Kinerja Karyawan. Jurnal Ilmu Manajemen, 2(3).

Sunyoto, D. (2011). Metodologi Penelitian untuk Ekonomi. Yogyakarta: CAPS.

Suryani \& Hendryadi. (2016). Metode Riset Kuantitatif Teori dan Aplikasi pada Penelitian Bidang Manajemen dan ekonomi Islam. Jakarta: Kencana.

Sutrisno, E. (2017). Manajemen Sumber Daya Manusia. Jakarta: Kencana.

Wibowo. (2016). Manajemen Kinerja. Jakarta: PT. Raja Grafindo Persada. 